\title{
Nation's Character Education Based on the Social Capital Theory
}

\author{
Siti Irene Astuti Dwiningrum ${ }^{1}$ \\ ${ }^{1}$ Yogyakarta State University, Indonesia \\ Correspondence: Siti Irene Astuti Dwiningrum, Yogyakarta State University, Indonesia. E-mail: \\ ireneast@yahoo.com
}

Received: August 1, 2013 Accepted: August 16, 2013 Online Published: August 30, 2013

doi:10.5539/ass.v9n12p144

URL: http://dx.doi.org/10.5539/ass.v9n12p144

\begin{abstract}
Multi-dimensional crisis faced by a country could weaken national character. The crisis in national character can deteriorate the social and cultural identity of a country, while there is identity that is necessary to maintain the existence of the country in the era of globalization. One of the factors that influence human nature is a weakened role of social capital. This study aims to describe the elements of social capital that is owned by the school, and the role of social capital in character education. The population of this study is the schools in the city of Yogyakarta, Indonesia. Sample were recruited from among teachers and principals from 17 elementary schools, 18 lower secondary schools and 16 high schools. The criteria for selection of schools are based on various levels of academic achievement. The data are collected from in-depth interviews and a questionnaire consisting of open-ended questions administered on the principals and teachers. The questions used are adapted from a questionnaire on social capital measure written by the World Bank. The steps taken in the process of analyzing qualitative research is data collection, data reduction, data display, conclusion, and data validation. The results of studies have concluded that school social capital and tried to strengthen elements such as (a) participation and social networks, (b) reciprocity, (c) trust, (d) social norms, (e) social value, and (f) proactive action. It was found that elements of the social capital are needed to support character education and to rebuild the country's power to face global challenges. Social capital as a collective force should be reconsidered as a socio-cultural force that strengthens the nation character. The elements of social capital play an important role in the process of character education in the family, school, and community. This can build the character of 'bridging social capital in a synergistic way, the goals and functions of character education can be obtained optimally.
\end{abstract}

Keywords: social capital, character of nations, teachers and principals

\section{Introduction}

Globalization causes changes in social culture. Every human society would inevitable undergo changes. Communities often tend to change in terms of social values, social norms, behavior patterns, organization, authority, social interaction, and so forth (Soekanto, 2010).William F. Ogburn suggested that the scope of social change include cultural elements of material or immaterial, with particular emphasis on the great influence of the elements of the material culture on immaterial elements. Kingsley Davis defines social change as changes in geographical conditions, cultural material, composition of the population, both because of diffusion ideology or new findings in the community. Samuel Koening briefly states that social changes point in the changes that occurred in the patterns of human life. While Selo Soemardjan defines that social change is the change in the institutions of society in a society, which affect social systems, including in it the values, attitudes, and behavior patterns of peri groups in society (as cited by Soekanto, 2010).

Social change in culture if not responded and adapted can cause a crisis in character. Currently, there is a very strong tendency in the face of global challenges that people tend to experience a crisis that leads to destruction. As explained by Thomas Lickona that leads to the destruction of life marked by (1) increasing violence among adolescents, (2) using abusive language and words, (3) increasing influence of a strong peer-group strong in acts of violence, (4) increasing self destructive behavior (consumption, alcohol, and sex-free), (5) worsening of guidance and moral, (6) declining work ethic, (7) lowering of respect for parents and teachers, (8) lowering a sense of individual responsibility and community citizens. (9) prevailing dishonesty, and (10) appearance of mutual hatred and suspicious of one another (cited by Masnur Muslich, 2011:35). Disintegration of society is becoming a phenomenon in Indonesia, as well as several countries in the world. The impact of social disintegration would trigger the occurrence of a multi-dimensional character of the crisis. 
Character crisis is a social phenomenon that occurred in the majority in the world. Many of the factors that caused the crisis occurred in tandem with the changing character of the community. For Indonesia crisis character as defined by Gede Raka (2007: 4-6 as cited by Dwiningrum 2010: 51 ), among others: a) perceiving that existing natural resources as equivalent to wealth of the nation whereas the natural resources should be treated by a process that requires human intelligence. Without the intervention of human intelligence resources still have no or low value, but it can be a source of disaster; b) economic development is too focused on physical capital. Measures of success that we are proud of the development of even more of a large part of physics that ignores the expansion of the non-physical capital, or capital materialized or virtual capital, such as the intelligence level of the people, the development of national character, which thus became the main focus of the economic development of nations in world; c) decrease in idealism and increase in pragmatism. The tendency to prioritize short term economic outcomes have made part of the community to be caught up in the pragmatism of overdoses, and then get stuck in attitude or behavior 'purpose justify the means'. When idealism is no longer important, many people believe that honest people cannot thrive economically, d) Less successful people learn from the experience of their own people.

Character crisis occurs in all nations, so that efforts to overcome the crisis character indeed are the responsibility of the citizens within the country and between countries in the era of globalization. Problems in socio-culture in the era of globalization are triggered by technological developments that occur ahead of the people that the effects of changes spread very fast in the society. Social disorganization and social conflict become a social phenomenon that occurred in the country and between countries in the global era. Social harmonization is becoming more difficult to create as there are differences in interests in the global community. Conflict of interests happens at all levels of life such as family, school, work and society. The social reality is that the community is facing with differences which are growing sharply and the energy needed to build the strength of the nation is getting weakened by the problems in life. Education is expected to play a role to strengthen and rebuild social values, as well as and reorganize various social interests in overcoming the crisis caused by social disorganization. In such event, character education is hoped to expand the potential of human resources which is needed to develop the progress and quality of life of the people.

Character education is expected to overcome the crisis that occurred in the character of the global community and play a role in developing human potential optimally as well as develop patterns of thought and behavior of students who are responsible for the conduct of social roles in the family, society and citizens. In such event, the principles of character education have been carried out in the practice of formal education, non-formal and informal applicative expected to be applied in the life and national character education. Government policy is widely applied in the management of national character education, as that occurred in Indonesia. Character education efforts are legally-organized as formal education strategic plan 2010-2025. As national character is reflected in national policy development, national character in term of the macro scale and micro scale is described as cooperation in the process of national character education as follows:

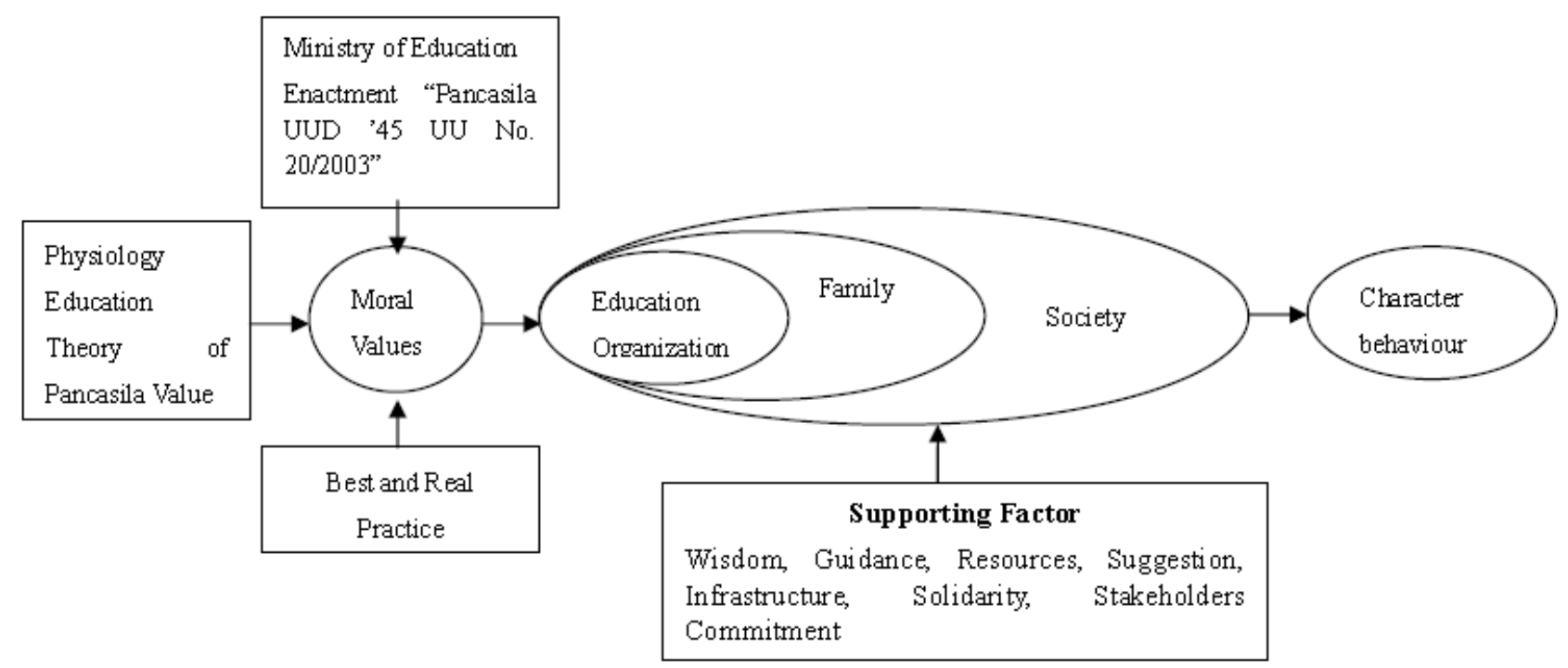

Figure 1. Macro context of character education 
Chronology of the national policy on education nation's character proves that character issues must be addressed jointly by all members of Indonesian society. In addition, character education must be done with a holistic and contextual approach for maximum results. As explained by Dwiningrum (2011) as problem is a structural crisis of character, character education should be done in a holistic and contextual manner. Structurally meaningful character of the Indonesian nation building starts from the family, school, community and country. The model developed is an attempt to make character education in a holistic manner involving aspects of "knowledge, felling, loving, and acting" (Ratna, 2005: 2). While the contextual aspects related to the core values necessary to form the character of the nation's power began to be internalized at every level of society. With a holistic approach and contextual can shape the character of people in all walks of life. As explained by Thomas Lickona (1991) who defines the nature of the character as a person in response to the moral situation, which is manifested in concrete action through behavioral conditioning, honest, responsible, respectful of others and other glorious character. As expressed by Aristotle as closely related to the characteristics of habit or custom made continuously. So the concept is built on this model is the habit of the mind, habits of the heart and habit of the hands (Ratna, 2005: 1; Dwiningrum, 2011).

Character education is designed and developed by different governments differed between countries. For Indonesia, character education has been designed within the framework of macro and micro. However, the crisis is not only based on the character of the government's policy on education of character, but which must be considered is the socio-cultural approach that character education process to resolve the crisis that has occurred in the level of people's lives, the social capital approach.

Social capital is an important element that is expected to help to overcome the problem of the crisis of character in the socio-cultural perspective. Social capital in the social life, but the power of social capital is not the same in every level of society. Social capital can be mapped back as the collective energy that can move people's participation in building the consciousness of the life of nation and state in the global era. Social capital can be reinforced in education in the family, school and community by strengthening the basic elements of social capital by building social synergists. In this paper will be presented in two main points namely how social capital can play a role in the education of the nation's character?

\section{Social Capital and Character Education}

In public life where there is a very strong trend, the role of social capital weakens. Social capital is a very important aspect in the life of nation building and social citizenship. Social capital has become an interesting area of study because social capital is a resource that can be seen as an investment to acquire new resources. As is known that something is called resources is something that can be used for consumption, saved, and invested. Resources used for capital is called investment. Dimensions of social capital are quite extensive and complex. Social capital differed with other popular terms, namely human capital. Human capital refers to more individual dimensions such as power and skills possessed by an individual. Social capital places more emphasis on the potential of the group and the patterns of relationships between individuals within a group and between groups with a focus on social networks, norms, values, and trust among the members of the group and was born from a group norm of social capital has an important role in build national character, because the character of a nation is determined by the existence of the state in maintaining a culture of true identity. The community is confident that cultural identity has an important role and is largely determined by the ability of its people in maintaining their social capital.

The term social capital was first used by Hanifan (Tjip de Jong, 2010) which represents the term as a property of the local community based on noble desires, associations, sympathy, and social relationships (Hanifan,1920 in Tjip de Jong, 2010). Hanifan described social capital as a resource that can be used to increase the glory of a local community (Smith, 2005). In the use of the phrase social capital, there is no reference made capital refers to the meaning usually, except in the figurative. Hanifan refers to social capital as:

Those tangible substances that count for most in the daily lives of people: namely goodwill, fellowship, sympathy, and social intercourse among the individuals and families who make up a social unit. The individual is helpless socially, if left to him. If he comes into contact with his neighbor, and they with other neighbors, there will be accumulation of social capital, which may immediately satisfy his social needs and which may bear a social potentiality sufficient to the substantial improvement of living conditions in the whole community. The community as a whole will benefit by cooperation of all its parts, while the individual will find in his associations the advantages of the help, the sympathy, and the fellowship of his neighbors (Tjip de Jong, 2010).

Loury (Tjip de Jong, 2010) uses the term in the context of social capital as a form of criticism of the neoclassical theory of racial income inequality and the implications for policymakers. Loury argues that orthodox economic 
theories are too individualistic, focus exclusively on individual human capital and the creation of level playing field for competition based on the skills (Portes, 1998 cited by Tjip de Jong, 2010). Equal opportunity programs will not reduce racial disparities. This could go on forever as described by Loury, that first black parents because of poverty will be sent to their children in the form of material resources and lower educational opportunities. Second, the social context in which individual maturation occurs and individuals can achieve competency. Loury's (1977) study as cited by Tjip de Jong (2010) captured the differential access to opportunities through social relationships for minority youth, but there is no systematic relationship to remedy other forms of capital (Portes, 1998; Tjip de Jong, 2010)

Social capital is understood to include virtually everything relating to embedded social: from the help of neighbors to civic morality to global world community. Despite the undeniable progress in theoretical specification, implementation methodology, and empirical application of this concept, understood as social capital remain essentially unchanged. The following contribution runs from the assumption that the inaccuracies in the use of the concept is generally the result of a different conceptual approach that is social and resource control over social relations. The second aspect of reality can be interconnected. Differences between individuals are more 'as opposed to a more' collective 'social capital. Classic definition of the term has included this double nature, Pierre Bourdieu, for example, considers social capital as the sum of 'actual or potential resources associated with long-lasting relationship proprietary mutual acquaintance and recognition '. This means that the individual can invest for mutual benefit. Robert Putnam, on the other hand, the working conditions of its contribution to democracy, likened more to the distribution of social capital and collective norms binding and bridging the colony if separated, the result of lower transaction costs and thus benefit all people individually, including their that do not invest in it. In this view, 'community' is 'social capital 'conceptual cousin. This mix of individual and collective aspects of social capital is expressed most clearly by the definition proposed by James S. Coleman. According to Coleman, social capital is 'not a union, but a variety of different entities having two characteristics in common. They all consist of some aspect of social structure and they facilitate certain actions of individuals who are in structure '(Coleman, 1990; Dario Castiglione, 2008: 24). The difference between individual and collective aspects of social capital becomes clear when examining specific resources and benefits provided by the client and the network. At least there are six special distinguished forms of social resources:

a) access to information and certain types of social life through relationships;

b) readiness to be honest in order to risk with other actors;

c) Production support, assistance, solidarities;

d) the availability of social control and a certain level of concern for the fate and actions of other members from around the network;

e) belief in climate networks, such as between colleagues from research institutes;

f) The validity norms, values, and morality in a group, organization, community.

This concurs with the analysis developed by James Coleman which was discussed further by Pierre Bourdieu and popularized by Robert Putnam. According to James Coleman (1990), the results of his studies on youth and schooling defines the concept of social capital as a variant of the entity, consisting of a number of social structures that facilitate the actions of the perpetrators, whether in the form of personal or corporation in a social structure. Social capital is inherent in the structure of relationships among individuals. The structure of this network of relations and create a broad spectrum of social responsibility, create a climate of mutual trust, bring information channels, and set the norms and social leery of its members (Hauberer, 2011:249). Coleman's analysis proves that the very important role of social capital in developing strong social relationships in the social structure.

Social relations in the structure of society have a role in developing the nation's cultural identity. In this context, developing the cultural identity of the nation that is to defend the self-esteem of a nation that has a specificity and uniqueness As described by Pierre Bourdieu who emphasized on different aspects of social capital that is required will provide useful support-support, self-esteem and respect of capital often needed if people want to attract clients into positions that are socially important, and that can be a medium of exchange, such as a political career. Social capital is the sum of resources, actual, gathered on an individual or group because of a long-lasting form of networks of reciprocity and recognition of many institutionalized introductions (in John Field, 2010:23).

Social capital needed in shaping the cultural identity of the nation. In reality, the nation's cultural identity is clashed with a global culture that reflects the values that are universal. According to Zamroni (2011), globalization is marked by the increasing economic interdependence, cultural, environmental, social and 
cross-country free range, and the emergence of form and process homogenizing tendencies, hybridization and differentiation culture (values, norms, and behaviors community) globally. As the impact of globalization reflects the cultural identity of self-reflection or self-image that every down from our families, gender, culture, ethnicity, and individual socialization process "(Ting-Toomey) increasingly strong, but there is a tendency to melt in a global culture. This situation will result in lowering the national character. That is, people tend character crisis caused by weakening and loss of cultural identity of the nation.

Cultural identity of people who are weak is becoming a social phenomenon, which is caused by the shift of social and educational role of the board in carrying out its social function. Cultural identity is usually formed through three levels namely personal illustrating that in the individual there is something unique; relational level that reflects our relationship with other social-cultural level that reflects the large-scale communities such as race, ethnicity, gender, religion or political affiliation. Cultural identity as a common culture, a group of self-esteem that hide in other things, more superficial or self-esteem that far-fetched, that the people with the same culture and share the same ancestry. In this definition, our cultural identity and common historical experience shows the values of the same culture that gives us, as one, with scenes from the reference and meaning of the static and continuous (Hall, 1993, 2011). The process of cultural identity formation encountered many obstacles, because conflicts continue to occur in the global community. Analysis of the cultural identity of the nation is more focused on the third level ie community level, as it is associated with the formation of national character, but in the process relationships between personal and relational identity formation can not be separated and thus amplified by the availability of social capital.

In this case there are two things that will be analyzed in this paper that is the very character of what is needed by a nation that can maintain the character of the nation, and second how the role of social capital that is required to form a national character. Value is an important element in human life, even becomes the foundation of forming a characteristic behavior. There's a lot of value, developed by the community to form a national character. In particular grand design developed by the Indonesian Ministry of Education (2010), a social psychologist and cultural formation in the individual character is a function of all potential human individual (cognitive, affective, and psychomotor) in the cultural context of social interaction in the family, school, and community and last throughout life. Totalities character configuration in the context of the psychological and the social-cultural can be grouped in the liver, if thought, athletics and though feeling and intention, with the character of the core can be described as follows:

\begin{tabular}{|l|l|}
\hline \multicolumn{1}{|c|}{ Cluster Configuration Character } & \multicolumn{1}{c|}{ The essence of character } \\
\hline Heart & Religious, honesty, responsibility, social care, care environment. \\
\hline Mind & Intelligent, creative, fond of reading, curiosity. \\
\hline Sports & Healthy and clean \\
\hline Feelings and intention & Care and collaboration \\
\hline
\end{tabular}

According to Thomas Lickona (1991: 53-62), character education should pay attention to three components namely: Knowing morality, moral feeling and moral action, in which the cover the following aspects:

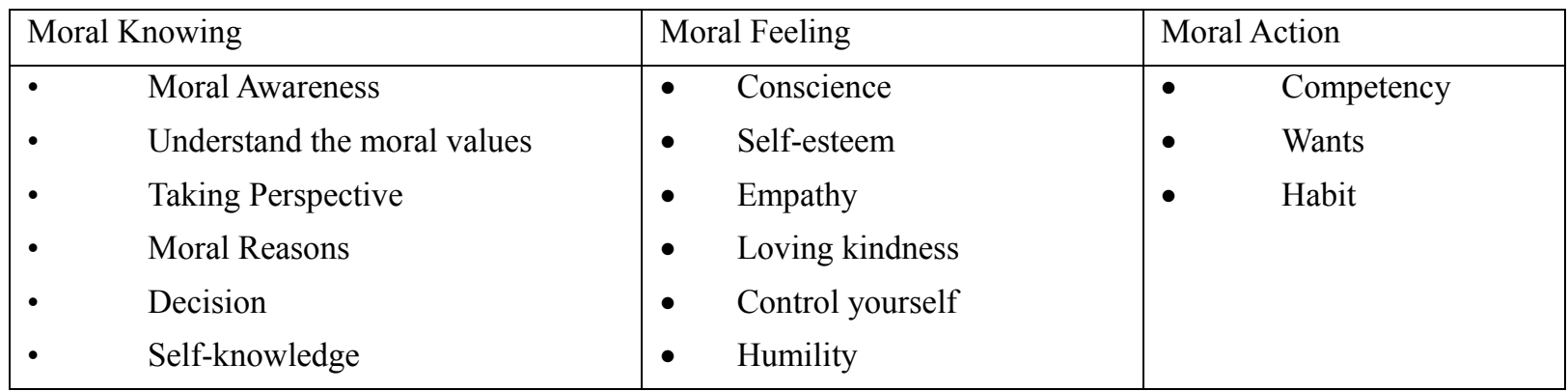

Configuration developed in character education as a result is determined by a highly dynamic process of socialization in order individuals, families and communities. In the context of community life that occurs more complex because there are many variants to be influential in the process of social interaction in character education. In practice many strategies and programs selected for character education process at all levels of education, as is the case with learning experiences, structured learning experiences, life situation etc. persistence. However, variations in the education process are determined by the role of social capital.

Social capital needed in the process of character education for social interaction requires social energy to be 
successful character education purposes optimal in macro or micro scale. Social capital needed in character education by expanding the elements of trees in social capital should be understood by all citizens of the community. As explained by Nan Lin on the concept of social capital in relation to the various important aspects of human life. According to Nan Lin, Social capital is rooted in social networks and social ties and understood as resources embedded in a social structure which are accessed and / or mobilized in actions aimed at. Thus, social capital contains three components: structure, opportunity or accessibility through social networking, and action (Lin, 2004: 40). In the context of character education, the social capital is needed in developing community structures, social networks and shaping the behavior of character.

Nan Lin explains that the actor accesses to social capital, through interaction, to promote purposive action. Thus, the nature of accessible resources embedded in the interaction becomes important in the analysis of purposive action and social interaction patterns. This can present the hypothesis of action and interaction typology. Two types of interaction that is relatively homophilous, where partners share the same resources, and the interactions heterophilous, where partners share different resources. (Lin, 2004:48).

Social capital in the process of character education can pass by the interaction of nature and heterophilous homophilious. Differences will bring effectiveness to achieve the purpose of character education. In addition, the nature of social interaction will affect the strength of the elements of social capital that is owned by the community. In addition to the main-forming elements are also other elements of social capital formation that is also not less important role. These elements can be considered as a condition of adequacy or sufficiency from forming or awakening power of social capital in a community. As for the elements in question is (Riza, 2006: 9-16): (a) participation in social networks, (b) the interchange of kindness or reciprocity, (c) inter-faith or trust, (d) social norms, (e) social values, and (d) the proactive action. Mapping the social capital associated with the element of playing this game of social capital. Analysis of the role of social capital is built based on objective analysis and critical thinking.

This is the case, between the capital element of the inter-related with others. To understand the principal elements of social capital needed in character education, character education process will not only focus on the determination of the character values only, but more important is the strengthening of social capital at all levels of society, so that social interaction that occurs in the process of character education can run more optimally realize the goal of character education (Sahid Hamid Hasan et al, 2010:7) and the main function of character education (Zubaedi, 2011: 18).

\begin{tabular}{|l|}
\hline \multicolumn{1}{|c|}{ The purpose of Character Education } \\
\hline $\begin{array}{l}\text { 1. Develop potential heart / conscience / } \\
\text { affective learner; }\end{array}$
\end{tabular}

2. Develop habits and behavior of the students is commendable and in line with universal values and cultural traditions;

3. Instill a spirit of leadership and responsibility as the next generation of learners race;

4. Develop students' ability to be an independent man, creative, and national vision;

5. Develop within the school as a learning environment that is peaceful, honest, full of creativity and friendship, and with a high national feeling and full strength

If analyzed from the description above that in reality, the purpose of character education to this day still has not managed to set the maximum, so that no single character education functions according to what is prescribed by the impact government is still the question of the emergence of various races crisis. Therefore, character education process should continue on dynamic, ongoing and continuous in the individual, is engaged in social life. Socialization and internalization of character values continue to be done by the family, school and society in accordance with the strength of social capital. In this case the dimensions bonding social capital and bridging social capital cannot be separated in the process of character education. Bonding social capital tend to have the strength and goodness in cooperation between members of a particular group, do reciprocal social interactions 
between individuals such as teachers, students, parents and in order to mobilize its members in the context of social solidarity to develop critical consciousness about the crisis of character . On the other hand, bridging social capital can mobilize broader identities and reciprocity are more likely to grow in accordance with the principles of character education that can be universally accepted (Riza, 2006:31). In the context of character education will work very well if the bridging social capital in more movement to exert pressure on the dimensions of "fight for" the search for answers leads to joint to solve the problems faced by the group or problem related to the effort to overcome the crisis of character over powered by all community level, so that the effect of the strengthening of social capital positip really much felt by all members of society alike are struggling in building national character. While social capital is sometimes unclear, because colored by the spirit of "fight againts" that is fighting back against the threat form the symbol of the possibility of collapse and traditional beliefs of the group. In this group, the dominant behavior is simply a sense of solidarity making. For this reason, the character education necessary to build bridging social capital, as judged capable of bridging social capital contribute to the development and advancement of community strength (Riza, 2006: 32). This is very important, because the process of character education can be formed by bridging openness, have a flexible network, tolerant, allowing to have an alternative answer and problem solving crisis character, accommodating, tend to have an altruistic attitude, humanistic, and universal in developing character education strategy.

\section{Research Purpose}

This study aimed to describe the elements of social capital in the school according to school principals and teachers view. This study was conducted to determine how social capital influences the national character education.

\section{Methodology}

Population studies are schools in Municipality of Yogyakarta, Indonesia. Study sample are school principals and teachers from 17 elementary schools, 18 junior high schools, and 16 high schools. Schools are selected based on criteria that are derived from a variety of school-level academic performance capabilities. -Descriptive study with a qualitative approach. Data were collected by in-depth interviews and fill out a questionnaire that asks open to the principal and teachers of social capital from written questionnaires by the World Bank about the measurement of social capital.

The first step in the process of data analysis is data collection in the field. Second, data reduction means making inclusion, choose a tree matters, focusing on the important stuff, finding themes and patterns, and throw it deems necessary. Third, after the data reduced, further analysis step is display of data. Catering direct data so that data reduction results organized, structured in pattern making it easier to understand. Data presentation can be in the form of a narrative description, chart, relationships between categories, flowcharts, and others like it. Fourth, draw conclusions based on the findings and verify the data. Preliminary conclusions presented is temporary and will be changed when found strong evidence that supports the following data collection. The next step, the data is interpreted according to the purpose of the study. The result is shown in this paper is part of research on mapping social capital in schools in Yogyakarta done together Suyata and Sadiq A. Kuntoro (2011). In the process of data analysis based on these findings early, so the results of this study have not been reached on the final form of conceptualization, because still required some research to do critical dialogue with the theories of social capital.

\section{Results and Discussions}

Analysis of data on social capital owned by the school at the elementary, junior proved that social capital is owned by the dynamic nature of the school. This corresponds to the strength of social capital are likely not the same school, because social capital is a resource that can be viewed as investment for new resources. As you know that something called resources is something that can be used for consumption, saved, and invested. Resources used for capital investment called.

Dimensions of social capital are quite broad and complex. Social capital at school more emphasis on the potential clusters and patterns of relationships between individuals in a group and inter-group with spatial attention on social networks, norms, values, and beliefs that come from peer group members and a norm group. Forming elements of social capital important role of school as a condition of adequacy or sufficiency to which elements are (a) participation in social networks, (b) the interchange of kindness or reciprocity, (c) social norms, (d) social values, and (e) the proactive action. (Riza, 2006).

Results of the research concluded that there is a tendency of social capital is stuck in school life. Schools generally have the potential of social capital but not developed optimally, so the effect of the existence of social 
capital has not been evaluated as an important part of the proponents of social capital improvements. In fact there is a strong tendency that the school already understands the existence and role of social capital for improvement of school quality. Strengthening social capital can be done subconsciously by all components of the school community who have mutual agreement that social capital is a very important aspect and the need to improve quality of education, and as a force for shaping the character of the nation. Consensus is built based on mutual awareness that social capital functions as a source of social control, as a source of family support and as a source of extra-profits through family networks (Portes, 1998 in Nan Lin). What is conveyed by Portes prove that the school social capital is necessary to create an environment that can develop an effective school culture for personal development resources that character. In that case, the school has an important role in personal and social development of students and intellectuals as part of the cognitive process of character formation of students.

In such event, the school program was designed on the basis of specific curricula, programs extracurricular require social capital in the process, because students generally have not understand the effect of the learning process or presence in a community or group will have an impact on the ability of students to develop a relationship and social network later in the day. On the other hand, social capital needed in the emotional development of students, particularly to developing a sense of, well, a sense of confidence. The question faced by schools is to overcome the exclusivist tendencies that weaken the strength of social capital measured. Another thing that faced by schools in developing social capital is the decision of the school that gives students the doubt on late for school, absences and less able to follow the normal learning activities due to lack of awareness of the importance of being social relations in various occasions.

In particular the results of this study concluded that the elements of social capital that is owned by the school can be summed up as follows:

Table 1. Role of social capital in character education

\begin{tabular}{|c|c|}
\hline $\begin{array}{l}\text { Element of school social } \\
\text { capital }\end{array}$ & description \\
\hline $\begin{array}{l}\text { Participation in } \\
\text { networks }\end{array}$ & $\begin{array}{l}\text { - Improve school life } \\
\text { - There is consultation with all members of the } \\
\text { - Autonomous schools are strong enough compared to } \neg \text { outsiders. } \\
\text { - Members have the right to choose a leader } \\
\text { - The main sources of funding from outside the local community } \\
\text { - Have access to information } \\
\text { - Creating social networks is not limited to the same social class. }\end{array}$ \\
\hline Exchange of kindness & $\begin{array}{l}\text { - Provide services to its members } \\
\text { - Build the interaction with other schools that have similar goals } \\
\text { - Sources of expertise or the most important advice is received from the } \\
\text { membership }\end{array}$ \\
\hline Trust & $\begin{array}{l}\text { - Ability to learn from each other and trust each other. } \\
\text { - Build togetherness in the distinction. }\end{array}$ \\
\hline Social norms & $\begin{array}{l}\text { - The level of security sufficient criminal acts or violence } \\
\text { - There was togetherness and the familiarity of the school community } \\
\text { - Respect the distinction-a distinction there. }\end{array}$ \\
\hline Social values & $\begin{array}{l}\text { - The neighborhood is quite peaceful with no violence. } \\
\text { - Teachers and principals are by and large feel quite happy, }\end{array}$ \\
\hline Proactive actions & $\begin{array}{l}\text { - The mass media is necessary for the social networking media as a source of } \\
\text { information on the process of social interaction } \\
\text { - Has the power to make decisions been largely able to turn his life around? } \\
\text { - Many attended a meeting with the village board / environment or public } \\
\text { meetings }\end{array}$ \\
\hline
\end{tabular}

Sources: compiled from the primary data, 2011 
Exposure data on social capital tend meaningful that is already embedded in school life. Even schools in general have the potential of social capital but not yet developed, so that the effect of the existence of social capital has not been considered as an important part of the process of improving the quality of school support, in particular to support the process of character education.

Nevertheless, the school continues to strengthen social capital with some important steps that starting from the strengthening of the elements of social capital that is owned by the school, the first of more to participate in various social networking revamp its existence as an educational institution that is trusted by the community to develop the potential of students as a source of personal power that is able to share in the local community or school community (participation and social networks), the second condition heterophilious interaction to exchange the good for students to develop social resources (reciprocity), third, build a culture of schools to maintain order and social discipline (social norm), fourth, instilling trust and confidence and responsibility and cooperation as an important capital to strengthen social capital, fifth on the all stakeholders to develop the ability to act proactively in response to the changes that continue to occur. In addition, the results of this study also concluded there that the same trend, namely teachers and principals of elementary schools, junior high schools attend more board meetings with village / neighborhood or other public gatherings. They more frequently perform routine activities in their villages rather than respond to common issues that are under consideration. The reality that describe activities that tend to do more towards social activity that strengthen social capital, compared with more individual activities. Other measures undertaken by the school is building students' motivation to perform better appreciate the association with individual distinction in building social cohesion through collaboration and a strong belief among students in maintaining and sharing common goal. Furthermore, social capital for the underlying qualities of the school improvement process moves from the social interaction that develops learning activity able to motivate all the basic needs of science students according to its own needs, by developing a strong association to unite the spirit of togetherness in improving student achievement to be used as part students as a means to build a united front in dealing with the problems of life, especially in the face of a crisis of character.

The research results proved that strengthening social capital can be done by all components of the school community who have an agreement that social capital is a very important aspect of character education and necessary for the nation. This is in line with the opinion of the Portes (1998) built that agreement based on mutual awareness that function of social capital as a source of social control, as a source of family support and as a source of benefits through extra-family network. What was delivered by Portes prove that for school social capital is needed to create an environment that can build an effective school culture for the development of students' personal resources. In this case the school has an important role in students' personal and social development as well as intellectual cognitive process of character building of students.

Similarly, the school program is designed on the basis of specific curricula, programs extracurricular require social capital in the process, because students generally do not understand the effects of the learning process or presence in a local community or group will have an impact on students' ability to build relationships and social networks in later on. On the other hand, social capital needed in the emotional development of students, in particular to build a sense of belonging, well-being, self-confidence. Problems experienced by schools is to overcome the tendency to exclude which assessed weaken the power of social capital. Another thing that is faced by the school in building social capital is the decision of the school authorities to punish the students who are late to school, absences and less able to follow the normal learning aktiviti due to the lack of consciousness of the importance of social relationships in a variety of occasions.

Social capital is needed in the formation of national character. Synergists between the role of family, school and society determine the role of strengthening social capital. Social capital is owned by the school is not enough to build the nation's character. Therefore, social capital must be developed comprehensively in national life who appreciates the power of localities. Based on these results, it should be constructed conceptually understanding holistic and structural in character education in the nation's social capital perspective can be described as follows (Dwiningrum 2012):

Based on the analysis of the characters and elements of social capital, the role of social capital in the character education can be described as follows: 
Table 2. Role of social capital in character education

\begin{tabular}{|c|c|}
\hline $\begin{array}{c}\text { Element of } \\
\text { social capital }\end{array}$ & Character Education \\
\hline $\begin{array}{l}\text { participation } \\
\text { and social } \\
\text { network, }\end{array}$ & $\begin{array}{l}\text { Character education requires social capacity able to build associations and social networks } \\
\text { are capable of forming pattern synergist relationship between families, schools and } \\
\text { communities to develop the principle of voluntarism, equality, freedom, and behavior or } \\
\text { civility to achieve character education goals. }\end{array}$ \\
\hline reciprocity, & $\begin{array}{l}\text { Character education requires reciprocal patterns constructed by a high level of social } \\
\text { awareness, mutual help and mutual respect to the social relations that occur in families, } \\
\text { schools and communities to function character education can build the nation's character. }\end{array}$ \\
\hline trust & $\begin{array}{l}\text { Character education is in dire need of confidence (trust) in the process of social interaction in } \\
\text { an individual level, the level of social relations and social systems level. Social relationships } \\
\text { that are built based on a pattern of mutually supporting actions for the purpose of building the } \\
\text { nation's character. }\end{array}$ \\
\hline social norm & $\begin{array}{l}\text { Character education requires social norms play an important role in controlling the behavior } \\
\text { of character that grew up in the family, school and community. Social norms are necessary to } \\
\text { stimulate the ongoing social cohesiveness that needed stronger in character education. }\end{array}$ \\
\hline social values & $\begin{array}{l}\text { Character education is in desperate need of character values that are considered right and } \\
\text { important by all citizens. The values chosen in character education has an important role in } \\
\text { shaping and influencing the rules (the rules of conducts), and the rules behave (the rules of } \\
\text { behavior), which is intended to form the cultural patterns (cultural pattern) as a form of } \\
\text { cultural identity nation. }\end{array}$ \\
\hline $\begin{array}{l}\text { Proactive } \\
\text { actions }\end{array}$ & $\begin{array}{l}\text { Character education is largely determined by the strong desire of the members of the group to } \\
\text { participate and be involved in all of the educational process. Proactive behavior determine } \\
\text { the success of the process of character education as embodied in the spirit of liveliness } \\
\text { proactive behavior and a strong concern for always dig up the information needed to develop } \\
\text { the ideas, knowledge, and various initiatives of the individual level, group level for the } \\
\text { purpose of forming the character of the nation's strong and sturdy and address the problems } \\
\text { in the process of character education. }\end{array}$ \\
\hline
\end{tabular}

Sources: adapted from Hasbullah, 2006: 9-17, 2012 Dwiningrum

Based on the table above it can be concluded that in character education process there is a tendency in need of social capital. Similarly, inter-capital elements to each other intertwined. By understanding the basic elements of social capital needed in character education, character education, the process is not only focused on the determination of the values of the characters alone, but more important is the strengthening of social capital at all levels of society, so that social interaction that occurs in the process of character education can run more optimally in realizing goals of character education

The character values that are developed can be determined from the condition and situation of each level, as well as the strengthening of the family-level character by parents is not the same among families, among children. Similarly, at the level of the school, character education programs, announced by the government for primary, junior and senior high schools have differing value-laden character education. As for the society or the state, generally there are dominant values that are used by the state to build the nation's character. Nevertheless, elements of social capital that is also part of an important character values of "trust" is needed in the process of character education, both in families, schools and communities. Trusting relationships as a basis for establishing cooperation will build a sense of responsibility and a sense appreciated, which then will cause the trust to 
provide the trust, so the reciprocal (reciprocal trust). This relationship is crucial to success in the process of character education. Similarly, a relationship of trust with the people we know, but that trust is the belief in the social structure known as (thin trust) is indispensable for the development of the nation's character. To build the nation's character takes a relatively long time and trust is maintained. Therefore we agree with Fukuyama that building trust takes a very long time, but it is often easier it is destroyed. When a society experiences mutual distrust (distrust), then build cooperation and arrangements difficult to realize (Fukuyuma, 2007, 2007:47-42). That is, in this context maintaining trust in the life of the state is in need of strong social capital is able to move an important component in the education of character. Similarly, in a nation of character education in the perspective of social capital will not be stuck formality and dominance of state policy, but provides an opportunity for people to explore the values of local knowledge as a dynamic social force in the face of social-cultural change.

\section{Conclusions}

Functions of character education do not meet the government's plan which led to some of the nation's woes. Character education process should be carried out continuously both dynamic and sustainable in social life.

Crisis of national character are still happening in the life of the global community. Crisis requires character education character performed by all levels of society. Schools have an important role in strengthening social capital very educational character of the nation. Values required in character education contextually determined in accordance with the conditions of learners.

Character education successfully with optimal if it is supported by social capital. Strengthening social capital is done by strengthening the elements of social capital that is tailored to the purpose and function of character education. The elements of social capital that is needed in character education are (a) participation and social networks, (b) reciprocity, (c) trust, (d) social norm, (e) social value, and (f) proactive action is determined by the success of character education power of the elements of social capital are owned by families, schools and communities to develop social capital bridging.

Social capital in the national character education will reduce state uniformity in character education, but it will give people the opportunity to develop the values of local wisdom as part of the power of social capital is a dynamic form of social energy. Socialization and internationalization of character values must be sustainable in the family, school, and society as a force of social capital.

\section{References}

Baron, S. D. (2000). Social Capital:Critical Perspective. New York: Oxford University.

Castiglione, D. (2008). The Handbook of Social Capital. New York: Oxford University Press.

Dwiningrum, S. I. A. (2010a). A Holistic Approach to Overcome Crisis and Contextual Character in Indonesia. In Horizons Education, Yogyakarya, UNY, May 2010, Th. XXIX, Anniversary Special Edition. ("Pendekatan Holistik dan Kontekstual dalam Mengatasi Krisis Karakter di Indonesia", dalam Cakrawala Pendidikan, Yogyakarya, UNY, Mei 2010, Th. XXIX, Edisi Khusus Dies Natalis.)

Dwiningrum, S. I. A. (2010b). Model Development Learning Holistic Approach and Contextual In Character Education in High School. Research Report, State University of Yogyakarta. ("Pengembangan Model Pembelajaran Dengan Pendekatan Holistik dan Kontekstual Dalam Pendidikan Karakter di SMA", Laporan Hasil Penelitian, Universitas Negeri Yogyakarta.)

Dwiningrum, S. I. A. (2010c). Implementation of Character Education in ISBD with Problem Solving Approach. Research Report, State University of Yogyakarta. ("Implementasi Pendidikan Karakter Pada ISBD dengan Pendekatan Pemecahan Masalah, Laporan Hasil Penelitian, Universitas Negeri Yogyakarta.)

Dwiningrum, S. I. A. (2011). Character Education Strategy Course in Sociology Anthropology with Problem Solving Approach. Research Report, State University of Yogyakarta. ("Strategi Pendidikan Karakter Dalam Matakuliah Sosiologi Antropologi Dengan Pendekatan Pemecahan Masalah, Laporan Hasil Penelitian, Universitas Negeri Yogyakarta.)

Dwiningrum, S. I. A. (2012a). Reconstruction of Education and Strengthening Social Capital, National Seminar Proceding. (Rekontruksi Pendidikan dan Penguatan Modal Sosial, Proceding Seminar Nasional.)

Dwiningrum, S. I. A. (2012b). The idea of Social Capital Development in Disaster Prone Areas in Quality Improvement Schools. Research Report, State University of Yogyakarta. ("Ide Pengembangan Modal Sosial Pada Daerah Rawan Bencana Dalam Perbaikan Mutu Sekolah". Laporan Hasil Penelitian, Universitas Negeri Yogyakarta). 
Field, J. (2005). Social Capital (Modal Sosial). Medan: Bina Media Perintis.

First Design Character Education, Ministry of National Education in 2010 (Desain Induk Pendidikan Karakter, Kementrian Pendidikan Nasional 2010)

Fukuyama, F. (2007). Trust: Social Virtues and the Creation of Prosperity (Trust: Kebajikan Sosial dan Penciptaan Kemakmuran). Terjemahan, Yogyakarta: Qalam.

Groostaet, C. (2004). Measuring Social Capital. Washington: The World Bank

Hall, S. (1993). Cultural Identities and Diaspora. Jurnal Framework edisi 36. Retrieved June 30, 2013, from http://www.unipa.it/ michele.cometa/hall_cultural_identity.pdf

Hall, S. (2011). Culture \& Cultural Identity. Retrieved June 28, 2013, from http://www.faceweb.northseatle.edu

Hasbullah, J. (2006). Social Capital. Jakarta: M-R United Press.

Hauberer, J. ( 2011). Social Capital Theory. VS Reseach. http://dx.doi.org/10.1007/978-3-531-92646-9

Jong, T. D. (2010). Linking Social Capital to Knowledge Productivity: An Explorative Study on the Relationship Between Social Capital and Learning in Knowldge-productive Network. Bohn Stafleun van Loghum. http://dx.doi.org/10.1007/978-90-313-8210-1

Koesoma, D. (2004). Character Education (Pendidikan Karakter). Jakarta:Grasindo.

Lickona, T. (1991). Educating for Character: How Our School Can Do Teach Respect and Responsibility. New York: Brantam Book.

Lickona, T. (2004). Character Matters. New York: Touchstone.

Lin, N. (2004). Social Capital. Australia: Cambrigde University.

Muslich, M. (2011). Character Education: Multidimensional Crisis Challenge (Pendidikan Karakter: Menjawab Tantangan Krisis Multidimensional). Jakarta: Bumi Aksara.

National Policy, National Character Development, 2010 to 2025 years. The Government of Indonesia, 2010 (Kebijakan Nasional, Pembangunan Karakter Bangsa, tahun 2010-2025. Pemerintah RI, 2010)

Raka, G. (2006). Transformational teachers in Development and Nation-Building Character, paper, Oration Lecturer Prestigious Poltekes Level and National Level (Guru Tranformasional dalam Pembangunan Karakter dan Pembangunan Bangsa, Makalah, Orasi Dosen Berpretasi Tingkat Poltekes dan Tingkat Nasional), Jakarta: 10 Nopember 2006.

Raka, G. (2007). Character Building Education; Papers, College Park Students Oration (Pendidikan Membangun Karakter, Makalah, Orasi Perguruan Taman Siswa). Bandung 10 Februari 2007.

Ratna, M. (2005). Character Education: An Agenda for the Nation Moral Repair (Pendidikan Karakter : Sebuah Agenda Perbaikan Moral Bangsa). EDUKASI: Jakarta, September 2005.

Schuller, T. D. (2004). The Benefits of Learning: The Impact of Education on Health.

Soekanto, S. (2010). Sosiologi Suatu Pengantar. Jakarta: Raja Grafindo.

Suyata, S. A. K., \& Siti, I. A. D. (2011). Mapping Social Capital in the School City of Yogyakarta. Research Report, Graduate UNY. ("Pemetaan Modal Sosial di Sekolah Kotamadya Yogyakarta", Laporan Hasil Penelitian, Pascasarjana UNY).

Ting-Toomey. (2012). Cultural identity. Retrieved from http:// www.napavaley.edu

Zamroni. (2011a). Multicultural Education (Pendidikan Multikultural). Pascasarjana UNY.

Zubaedi. (2011b). Character Education Design (Desain Pendidikan Karakter). Jakarta: Kharisma Putra Utama.

Zuchdi, D. (2009). Character Education (Pendidikan Karakter). Yogkarta: Uny Press.

\section{Copyrights}

Copyright for this article is retained by the author(s), with first publication rights granted to the journal.

This is an open-access article distributed under the terms and conditions of the Creative Commons Attribution license (http://creativecommons.org/licenses/by/3.0/). 